The book by Draper is closer to the traditional approach to machine exposition than most of those written recently. This is not to be critical of it, but to indicate that it will meet a need for those who feel that the more fashionable approach is too far removed from practical devices and leaves the student with problems of visualization and appreciation. It is the second edition of the successful book which first appeared in 1956. This new edition follows the same pattern as the earlier one and is improved chiefly by the addition of a chapter dealing briefly with the principles and application of semi-conductor devices; also the treatment of the induction motor has been extended somewhat, and one or two ideas on closed-loop control are included. The treatment of sing'e-phase machines remains brief, and matrix methods, although referred to in the proface, are not seriously exploited; however, both these topics are treated in the author's comptnion text Electrical Circuits (including Machines), and cross-references are given. The present book is remarkable for the breadth of its coverage-all practically important machines, together with mercury-arc rectifiers, are included, even if briefly. That this should be possible without the treatment becoming unaccuptably superficial or scrappy is due to the author's commendably simple and clear style. Because of its coverage and its readability, this book will attract many students.

P. J. LAWRENSON

G. W. Carter

\section{TEXTILE CHEMISTRY}

\section{Textile Chemistry}

By R. H. Peters. Vol. 2: Impurities in Fibres; Purification of Fibres. Pp. xiii +374 . (Amsterdam. London and New York; Elsevier Publishing Company, 1967.) $135 s$.

IN the main this book comprises an excellent and detailed description of the industrial chemistry associated with the processes of scouring and bleaching of cotton and other cellulosic fibres. There aro chapters on the chenistry, scouring and bleaching of wool, and particularly on the fundamental work on the reactions of wool in aqueous media. There is some reference to man made and regenerated cellulose and its esters, and also to the aqueous reactions of silk fibroin.

The first chapter gives an account of the industrial uses and chemical content and contamination of water from various sources and forms a fitting introduction to the aqueous fibre chemistry which follows. There follows a detailed physico-chemical study of sequestering agents and co-ordination compounds. The bearing of this subject on dyestuff absorption is obvious, and in the next chapter ion-exchange phenomena are discussed with a strong mathematical accent on sorption and swelling properties of fibres. The fourth chapter is a rather short description of some of the natural fibres; possibly this could have been expanded with some added value to the book. A description is then given of the chemistry of sizes, gums and waxes and their technical applications are outlined.

There follows a series of chapters on the chemical technology of cotton and other cellulosic fibres. In this field, the book is sound and comprehensive and makes an excellent reference work in this field. The thirteenth chapter on linen and man made fibres is a useful contribution but in no way as comprehensive as the work on cotton. A similar comment can be made about the three chapters on wool chemistry and also the seventeenth chapter on the scouring and bleaching of wool. They do, however, give a general survey of the subject and the references are a useful guide to any reader who wishes for a more detailed study of the chemistry of wool and related products. The final chapter gives a comprehensive survey of the technical chemistry of the mercerization of cottion.

The book is the second of this series, and when the third volume is avai'able the series should make a valuable contribution in the field of the applied chemistry of fibres.

F. HAPPEX

\section{OBITUARIES}

\section{Cr Jan Kruszynski}

DR JAN KRUSZYNSKI, senior lecturer in histology in the University of Liverpool, died on October 14 aged 64.

Kruszynski studied medicine at the Stefian Batory University of Wilno. In his second year, his beautiful histological drawings came to the attention of Professor J. S. Alexandrowicz and soon led to a junior appointment to the teaching staff of the Department of Histology. Kruszynski graduated MD in 1930 and attained the degree of Docent in 1936.

He remained at the Department of Histology at Wilno until his capture by the Russians in 1939. He was a prisoner of war until 1941; he did not care to discuss his terrible experiences during that period. He joined the Polish Army in Russia in 1941, being appointed pathologist to a military hospital, with which he served as it travelled across the Caspian Sea to Italy, via Egypt, Palestine, Iraq and Persia. He reached Britain in 1947. He was appointed assistant lecturer in histology at Liverpool in 1948, lecturer in 1950 and senior lecturer in 1963.

Jan Kruszynski was a gentle, self effacing scholar who gave service of inestimable value to the department and to the medical school as a whole. He had a profound knowledge of classical histology, its literature, its methods and results. His artistic gifts made him a superb illustrator of histological appearances; he went to untold trouble on the students' behalf in preparing demonstrations and lectures illustrated by the clearest of diagrams and drawings. He was always ready to share his wide experience of histological appearances and was consulted by colleagues from many different departments about their problems. His own special research interest was in inorganic histochemistry; from an early stage in his career he was interested in microincineration and became recognized internationally, through lectures and published papers, as the chief authority in that field.

His hobbies reflected his artistic interests: art galleries, photography, engraving and country walking. $\mathrm{He}$ will be sorely missed, not only for his professional accomplishments, but for his cheerful, modest personality and the complete integrity of his character. N. M. Hancox

\section{Dr W. J. Rees}

$I_{T}$ is a great shoek to marine biologists in many countries to learn of Dr W. J. Rees' sudden death on October 12 at the age of 54 . He was born on July 2, 1913, and graduatod from the Univorsity of Wales at Aberystwyth in 1933 and was awarded the DSc in 1942. He is known internationally for his research on three distinct groups of marine animals.

His first research as a postgraduate student at Aberystwyth, was on the helminth parasites of molluscs. He gave this group up somewhat reluctantly in 1936 to become research assistant at the Plymouth Marine Laboratory where he started his researches on the Hydrozoa which were to prove his primary interest for the rest of his life. From 1940 to 1946 he served with the Royal Air Force Volunteer Reserve, first with Coastal Command and later 
with the Adiniralty where he became a leading authority on the recog.ition of fishing craft, writilg a series of books of refierence for the services on fishirig craft, first on those of western Europe and then on those of far eastern countries.

In 1946 Rees was appointed to the sciontific staff of the British Museum (Natural History) ard for the next eight years was in charge of the molluse section. During this time he published important pupers, ehiefly on the Cephalopod $i$, beirg specially interusted in giant squids, and he made very interesting investigations on the larval stages of the octopus in the English Channel. He also did sound work oil heteropods and terrestrial gastropods including a report for the Colonial Office on the giant snail, Achatina. He reviewed the breathing devices of terrestrial pulmonates and wrote on the aerial di persion of Mollusca. He did not, howevor, conceal his eagerness to return to work on the coelenterates and when the opportunity arose in $\mathbf{1 9 5 4}$ he was transferred to the coelenterate section as a principal scientific officer and was able to resume his researches on the Hydiomedusae. He d d not, however, abandon his interest in the mollusca and was president of the Malacological Society fiom 1963 to 1966.

Rees pursued his studes in many marine laboratories in Europe and latterly in the United States, and in addition to discover ing a number of new species of hydroid was often succossful in linking for the first time a known medusa to its hydroid, which was often known by a different name. His interest in the classification of the Hydrozoa culminated in an international symposium on "Cnidaria and their Evolution", which was effectively organized and edited by him for the Zoological Society of London.

J. P. Harding

\section{Dr P. D. F. Murray}

Dr P. D. F. Murray died suddenly on May 17 on board ship while on his way from Australia to Cambridge. He was one of Australia's most distinguished zoologists.

Murray was born on June 18, 1900, at Dorchester. $\mathrm{He}$ went to Australia at an early age and was educated at Riverview College and the University of Sydney, from which he graduated with first class honours and the university medal in zoology. He was awarded the Macleay Fellowship of the Linnean Society of New South Wales and began research work for which he was awarded the DSc. After staying for a few years as lecturer, he left Sydney and spent some time at the Universities of Freiburg and Oxford before taking up a Royal Society Smithson Research Fellowship at the Strangeways Laboratory at Cambridge. In 1936 he was appointed university demonstrator at Bedford College and three years later reader in biology and comparative anatomy at the Medical College of St. Bartholomew's Hospital.

In 1949 the Challis chair in zoology in the University of Sydney became vacant and Murray returned to take up this appointment. Ill health, however, forced him to relinquish it and in 1960 he went to the University of New England at Armidale in New South Wales, where he had been appointed reader in zoology. This position enabled him to pursue his research without the heavy load of administration that had undermined his health in Sydney. He retired from this post last year and the university honoured him by appointing him an honorary research fellow.

Besides holding the degrees of the University of Sydney, Murray also held a BSc from the University of Oxford and an honorary MA from Cambridge. When the Australian Academy of Science was established he became one of the Foundation Fellows.

Murray's research interests were in the field of experimental embryology and morphogenesis. While still at the University of Sydney early in his career he carried out work on the development of single somites, of unsegmented mesoderm and of the skeleton in chick embryos.
He used the technique of chorio-allantoic grafts, which, together with tissue cultures, became his major tech. niques in his later work.

After he left Sydney, Murray continued his research with studies on the development of the heart and the blood vessels and the effects of various cations on the heartbeat and the fibrillation in the developing chick heart. Later he concentrated on experimental studies of the skeletal tissues and during the past few years worked on the histology and the experimental induction of adventitious cartilage.

His research interests, however, do not tell the full story of Murray's role in academic life. He was a man of great modesty but of firm purpose. His clear mind and wide interests in many facets of biology, his integrity and disinterestedness, were generally acknowledged and caused his advice to be sought on many occasions. And because his taking up the position of professor of zoology came at the beginning of a rapid expansion of university teaching with the establishment of new institutions the calls on his advice, his time and his energy were many.

When he took up the readership in the University of New England he was freed from many of the more arduous tasks of administration. He could again concentrate on his research work and the supervision and stimulation of work of younger colleagues. On his retirement he looked forward with keen anticipation to a renewal of old friendships at the Strangeways Laboratory, where he intended to spend the next two years. His sudden death, depriving the world of an outstanding scientist, is therefore the more poignant and tragic.

Alex STOCK

\section{Professor Carl Kling}

Professor Carl Kling died in July at the age of 88 . $\mathrm{He}$ became interested in microbiology as a medical student, and after graduation joined the staff of the Swedish National Bacteriological Laboratory. He was appointed director in 1924 and held this post until his retirement in 1945.

In 1911 Sweden experienced what was to develop into one of the most devastating poliomyelitis epidemics ever recorded. Klirg dedicated himself to a study of the epidemiology of the disease and developed an almost obsessive interest in this subject which stayed with him for the rest of his life.

His most significant contribution came in 1929 when, after observations on several European epidemics and a re-evaluation of earlier laboratory findings, he concluded that poliomyelitis must indeed be an intestinal infection. This represented a radical departure from the generally accepted concept of poliovirus as an exclusively neurotropic agent. It took almost ten years and a great deal of confirmatory evidence to convince the medical world that Kling's ideas were essentially correct.

His hypothesis when first presented had rested partly on his intuition and power of scientific imagination. In the following years, in experimental studies of the patho. genesis and epidemiology of the disease, he added much of the substantial evidence that finally revolutionized the concepts of the natural history of poliomyelitis.

In later years he engaged himself in a less fruitless search for extrahuman virus reservoirs. He remained active long after his retirement; only in his last two years did age begin to dampen his spirits.

Under Kling's directorship the National Bacteriological Laboratory grew to acquire both national and international recognition and long served as Sweden's contral breeding place for the microbiological sciences. This development did not take place entirely without controversy. With his refreshingly nonconformist attitude to both life and science, Kling made a few enemies as well as many dovoted friends. With him Swedish medical science has lost one of its most colourful personalities. SVEN GaRD 